\title{
ASTMOS IR EOZINOFILINIO BRONCHITO SUKELTAS KOSULYS
}

\author{
PROF. PETRAS V. DIČPINIGAITIS
}

ALBERTO EINŠTEINO MEDICINOS KOLEDŽAS, NIUJORKAS

Reikšminiai žodžiai: kosulys, kosulio refleksas, astma, eozinofilinis bronchitas, kosulio astma, lètinis kosulys.

Santrauka. Kosulys yra vienas dažniausių simptomų, dèl kurio žmonės kreipiasi į gydytoją. Astma ir eozinofilinis bronchitas - viena dažniausių lètinio kosulio priežasčių. Straipsnyje aptariamos kosulio astmos ir eozinofilinio bronchito sukelto lètinio kosulio diagnostikos ir gydymo problemos.

\section{ASTMA}

Kosulys yra vienas dažniausių simptomų, dèl kurių pacientai kreipiasi i gydytoją [1]. Daugelis perspektyviųjų tyrimų rodo, kad astma - viena dažniausių lètinio kosulio priežasčių (apie 25 proc. atvejų) [2-4]. Daugelị astma sergančių ligonių vargina tipiški, astmai būdingi simptomai, kaip antai dusulys, švokštimas, bet dalis ligonių skundžiasi vieninteliu simptomu - kosuliu. Šie pacientai serga vadinamąja kosulio astma.

Sergant kosulio astma objektyvaus ir plaučių funkcijos tyrimo rezultatai būna normalūs. Astmos diagnozę patvirtina teigiamas bronchu provokacinis mėginys su metacholinu. Tačiau vien teigiamo bronchų provokacinio méginio su metacholinu neužtenka, kad būtų pavirtinta, jog lètinio kosulio priežastis - kosulio astma. Ankstesnių tyrimų duomenimis, tik 60 proc. pacientų, kurie skundèsi lètiniu kosuliu ir kuriems bronchų provokacinis mèginys su metacholinu buvo teigiamas, būtent astma lèmè kosuli [5]. Kitiems pacientams nustatytos kitos lètinio kosulio priežastys. Taigi lètinio kosulio atvejais teigiamas bronchų provokacinis mėginys su metacholinu dar nepagrindžia kosulio astmos diagnozès. Kosulio astmos diagnozè patvirtinama tik praejus kosuliui nuo vaistų, skirtu astmai gydyti.

Kosulio astmos gydymas nesiskiria nuo tipinès astmos. Kosulio astmai gydyti gali būti skiriama inhaliuojamųjų bronchus plečiančių beta 2 agonistų, inhaliuojamųjų ir geriamųjų gliukokortikosteroidų bei leukotrienu receptoriu antagonistu (1 lentelè). Klinikiniai tyrimai rodo, kad gydant kosulio astmą bronchus plečiančiais vaistais kosulys sumažeja jau po vienos savaitès. Tačiau, kad kosulys visiškai išnyktų, prireikia iki 8 savaičiu gydymo inhaliuojamaisiais gliukokortikosteroidais [5].
Praktikos gydytojams svarbu žinoti, kad kosulio astma sergantiems asmenims inhaliuojamieji gliukokortikosteroidai gali sustiprinti kosuli [6]. Tai lemia kosulị sukeliančios sudètinès purškalo dalelès. Gydymas inhaliuojamaisiais vaistais gali būti neefektyvus dèl netaisyklingos vaisto ịkvėpimo technikos. Jei manoma, kad astma yra létinio kosulio priežastis, o gydymas inhaliuojamaisiais gliukokortikosteroidas nepadeda ar net pablogina kosuli, kosulio astmos diagnozei paneigti ar patvirtinti galima skirti sisteminio poveikio gliukokortikosteroiduc kursą.

Leukotrienų receptorių antagonistai taip pat gali būti vartojami būtent kosulio astmai gydyti. Tyrimų duomenimis, zafirlukastas reikšmingai sumažino kosuli, kuris buvo neefektyviai gydytas inhaliuojamaisiais bronchus plečiančiais vaistais ir gliukokortikosteroidais, taip pat objektyviai sumažino kosulio reflekso jautrumą inhaliuojamajam kapsaicinui [7]. Kitas tyrimas rodo, kad monelukastas buvo efektyvesnis už placebą gydant ilgiau nei 4 savaites trukusi kosuli [8]. Patogeneziniai mechanizmai, kodèl leukotrienų receptorių antagonistai efektyvūs gydant kosulio astmą, nèra visiškai aiškūs. Manoma, kad šie vaistai moduliuoja eozinofiluc stimuliuojamąji poveikị kosulio receptoriams, esantiems kvejpavimo takų epitelyje [9].

Leukotienų receptorių antagonistai slopina astmos sukeltą kosulį. Tačiau nèra aišku, ar gydant astmą vien šiais vaistais lètinis kvèpavimo takų uždegimas nuslopinamas pakankamai. Sergant kosulio astma, nors ir mažiau nei tipine, kvejpavimo takų poepitelinis sluoksnis būna storesnis nei sveikų asmenų [10]. Tai rodo, kad kosulio astmai taip pat būdingas lètinis kvėpavimo takų uždegimas.

Kosulio astma nuo tipinès skiriasi ir pagal kitą požymị. Kosulio astmai būdinga padidèjęs kosulio reflek- 
1 lentelè. KOSULIO ASTMOS GYDYMO PASIRINKIMO GALIMYBÉS

Inhaliuojamieji bronchus plečiantys vaistai

Inhaliuojamieji gliukokortikosteroidai

Geriamieji gliukokortikosteroidai

Leukotirenų receptorių antagonistai (LRA)*

"LRA, vartojami vieni, nesumažina kvépavimo takų uždegimo ir neapsaugo nuo kvépavimo taku remodeliacijos.

so jautrumas kapsaicinui [7], o tipinès astmos atvejais jis nesiskiria nuo sveikų asmenų. Manoma, kad didesnị kosulio reflekso jautrumą sergant kosulio astma lemia medžiagai $P$ jautrūs imunoreaktyvieji nervai kvėpavimo takų epitelyje [11]. Idomu, kad sergant kosulio astma kosulio receptorių jautrumas yra didesnis, o bronchų reaktyvumas metacholinui mažesnis, palyginti su tipine [7, 12-14]. Tai puikus pavyzdys, rodantis, kad kosulys ir bronchų obstrukcija yra kontroliuojama skirtingu neurofiziologinių mechanizmų.

Kokia yra natūrali kosulio astmos eiga? Vieno tyrimo, kuriame 5 metus buvo stebimi 28 suaugę kosulio astma sergantys pacientai, duomenimis, 35 proc. tiriamujjų kosulio astma perèjo ì tipinę, pasireiškiančią švokštimu ir dusuliu [15]. Ilgesnè kosulio trukmè buvo tipinès astmos išsivystymo rizikos veiksnys. Kitu tyri$\mathrm{mu}$, kuriame kosulio astma sergantys asmenys stebèti vidutiniškai 4 metus (nuo 1 iki 12,5 metų), nustatyta, kad 17 proc. ju pasireiškè tipinė astma. Šio tyrimo duomenimis, didesnis pradinis bronchų hiperreaktyvumas buvo tipinès astmos išsivystymo rizikos veiksnys [16]. Trečiame tyrime, kuriame dalyvavo 42 kosulio astma sergantys suaugusieji, švokšimas 4 metų laikotarpiu prasidejo 31 proc. tiriamųjų. Tyrèjai nustatė, kad vienintelis požymis, skiriantis tuos, kuriems išsivystè švokštimas nuo tų, kuriems jis neišsivystė, buvo ankstyvas gydymas inhaliuojamaisiais gliukokortikosteroidais [17].

\section{EOZINOFILINIS BRONCHITAS}

Eozinofilinis bronchitas pastaruoju metu laikomas svarbia lètinio kosulio priežastimi ir yra įtrauktas ị naujausias Amerikos krūtinès gydytojų kolegijos gaires [18] Eozinofilinis bronchitas, kaip ir astma, sąlygoja lètini kosuli bei yra susijęs su kvẻpavimo takų eozinofilija (> 3 proc. eozinofilu indukuotuose skrepliuose). Tačiau ne taip kaip astmai, eozinofiliniam bronchitui nebūdinga grịžtama kvėpavimo takų obstrukcija ir padidèjęs bronchų reaktyvumas metacholinui [19]. Be to, putliosios ląstelès astma sergančių asmenų yra kvėpavimo takų lygiuosiuose raumenyse, o eozinofiliniu bronchitu kvėpavimo takų epitelyje [20] (2 lentelè).

Eozinofilinio bronchito sukeltas kosulys efektyviai gydomas inhaliuojamaisiais gliukokortikosteroidais. Dèl šios priežasties dažnai klaidingai diagnozuojama kosulio astma, nes daugelis gydytojų netiria skreplių eozinofilijai nustatyti ir neatlieka bronchų reaktyvumo metacholinui tyrimo. Eozinofilinis bronchitas yra gana dažna lėtinio kosulio priežastis. Vienas tyrimas,
2 lentelè. ASTMOS IR EOZINOFILINIO BRONCHITO PALYGINIMAS

\begin{tabular}{|c|c|c|c|c|c|}
\hline & $\begin{array}{l}\text { Skreplių } \\
\text { eozino- } \\
\text { filija }\end{array}$ & $\begin{array}{l}\text { Grịžtama } \\
\text { kvèpavimo } \\
\text { takų obs- } \\
\text { trukcija }\end{array}$ & $\begin{array}{l}\text { Bronchų } \\
\text { hiperreak- } \\
\text { tyvumas } \\
\text { metacho- } \\
\text { linui }\end{array}$ & $\begin{array}{l}\text { Atsakas } \\
\text { i IGKS* }\end{array}$ & $\begin{array}{l}\text { Putliụjų } \\
\text { ląstelių } \\
\text { lokaliza- } \\
\text { cija }\end{array}$ \\
\hline Astma & taip & taip & taip & taip & $\begin{array}{l}\text { kvèpavi- } \\
\text { mo takų } \\
\text { lygieji } \\
\text { raumenys }\end{array}$ \\
\hline $\begin{array}{l}\text { Eozinofi- } \\
\text { linis bron- } \\
\text { chitas }\end{array}$ & taip & ne & ne & taip & $\begin{array}{l}\text { kvėpavi- } \\
\text { mo takų } \\
\text { epitelis }\end{array}$ \\
\hline
\end{tabular}

kuriame dalyvavo lètinio kosulio varginami asmenys, lankęsi specializuotame centre, rodo, kad eozinofilinis bronchitas, kaip lètinio kosulio priežastis, nustatyta 13 proc. atvejų [21]. Pirminès sveikatos priežiūros grandyje eozinofilinis bronchitas lètinio kosulio priežastimi Ł̇vardytas 11 proc. atvejų. Pirminiais tyrimu duomenimis, dažniausiai eozinofilinis bronchitas būna lètinè liga, o astma ar stabili bronchų obstrukcija išsivysto tik nedidelei daliai pacientu [23].

\section{COUGH IN ASTHMA AND EOSINOPHILIC BRONCHITIS}

PETRAS V. DIČPINIGAITIS

ALBERT EINSTEIN COLLEGE OF MEDICINE, NEW YORK

Key words: cough, cough reflex sensitivity, asthma, eosinophilic bronchitis, cough variant asthma, chronic cough.

Summary. Cough is among the most common complaints for which medical attention is sought. Asthma and eosinophilic bronchitis are one of the most common courses of chronic cough. Diagnostic and treatment problems of cough variant asthma and eosinophilic bronchitis are discussed in this article.

\section{LITERATŪRA}

1. Burt CW, Schappert SM. Ambulatory care visits to physician offices, hospital outpatient departments, and emergency departments: United States, 1999-2000. Vital Health Stat 13, 2004;157:1-70.

2. Irwin RS, Curley FJ, French CL. Chronic cough. The spectrum and frequency of causes, key components of the diagnostic evaluation, and outcome of specific therapy. Am Rev Respir Dis 1990;141:640-647.

3. Pratter MR, Bartter T, Akers S, et al. An algorithmic approach to chronic cough. Ann Intern Med 1993;119:977-983.

4. McGarvey LPA, Heaney LG, Lawson JT, et al. Evaluation and outcome of patients with chronic non-productive cough using a comprehensive diagnostic protocol. Thorax 1998;53:738-743.

5. Irwin RS, French CL, Smyrnios NA, et al. Interpretation of positive results of a methacholine inhalation challenge and 1 week of inhaled bronchodilator use in diagnosing and treating cough-variant asthma. Arch Intern Med 1997:157:1981-1987.

6. Shim CS, Williams MH. Cough and wheezing from beclomethasone dipropionate aerosol are absent after triamcinolone acetonide. Ann Intern Med 1987;106:700-703.

7. Dicpinigaitis PV, Dobkin JB, Reichel J. Antitussive effect of the leukotriene receptor antagonist zafirlukast in subjects with cough-variant asthma. J Asthma 2002;39:291-297.

8. Spector SL, Tan RA. Effectiveness of montelukast in the treatment of cough variant asthma. Ann Allergy Asthma Immunol 2004;93:232-236.

9. Dicpinigaitis PV. Cough in asthma and eosinophilic bronchitis. Thorax 2004;59:71-72

10. Niimi $A$, Matsumoto $H$, Minakuchi $M$, et al. Airway remodeling in coughvariant asthma. Lancet 2000;356:564-565. 